\title{
Process and Product Quality Assurance MEASURES IN CMMI
}

\author{
Mahmoud Khraiwesh \\ Faculty of Science and Information Technology, Zarqa University, Zarqa - Jordan
}

\begin{abstract}
Process and product quality assurance are very important aspects in development of software. Process and product quality assurance monitor the software engineering processes and methods to ensure quality. It is the process of confirming and verifying that whether services and products meet the customer expectation or not.

This research will identify general measures for the specific goals and its specific practices of Process and Product Quality Assurance Process Area in Capability Maturity Model Integration (CMMI). CMMI is developed by Software Engineering Institute (SEI) in Carnegie Mellon University in USA. CMMI is a framework for assessment and improvement of computer information systems. The procedure we used to determine the measures is to apply the Goal Questions Metrics (GQM) approach to the two specific goals and its four specific practices of Process and Product Quality Assurance Process Area in CMMI.
\end{abstract}

\section{KEYWORDS}

Process, product, quality assurance, Measures, CMMI, GQM.

\section{INTRODUCTION}

Since software increasingly govern our society and becomes common and embedded in nearly everything we do. We have to make sure that systems work in a better way as we want. Software project measures are the discipline that ensures that the project is stay in control. Measurements of a software project apply to people, processes, and products[8].

The quality assurance of software involves product and process assurance. Process oriented approaches deal with the establishment of standards, principles, rules, guidelines, manuals, process definitions, and improvement of software quality processes. The high quality product is resulted from high quality development process [36]. The absence of process and product quality increase problems during software development project [15].

Process and product quality assurance are process driven approaches with specific steps to achieve development goals. The process and product quality assurance consider design, development, and production. Quality assurance is preventive approach from occurring by providing methods and rules. Quality assurance prevents defects from occurring. It starts in software development process from the early stages of SDLC. It grants confidence to customer regarding the software development process and the product. It is a systematic and planned pattern of all actions necessary to provide adequate confidence that a product or an item conforms to established technical requirements. 
The purpose of process and product quality assurance (PPQA) is to provide management and staff with objective insight into processes and related work products [35]. Process and product quality have become the key to success in software development lifecycle [18].

For the time being we know the fact that software measurement helps us to better understand, evaluate, and control the processes, products, and software projects from the perspective of controlling, evaluating, tracking, forecasting, and understanding [12]. A valid measurement process can provide organizations to make better and timely decisions to achieve success in software systems [19].

Measurement is a helpfully support tool for software management [26]. Measurement is an important factor to effective management of processes. Measurement is a mechanism for evaluating, identifying, and predicting for various software products and processes [2]. The best way to enhance software processes is to measure specific attributes of the process then define a set of related metrics based on the attributes of the process, and then use these metrics to define indicators that will lead to improvement planning. Measurements of software do an important function in understanding and controlling of software development products and processes [25].

In software measurement we give numbers or symbols to attributes of the selected entities in the real life in such a way to characterize the attributes by some defined rules [11]. Software measurement is important for the following main activities: understanding, controlling and improvement [13]. Measurements are used to assess achievement of goals, to determine status according to plans, to gain understanding of resources, environments processes, and products, to establish principles for comparisons with future evaluation and follow improvement efforts [31]. The main measurement objective is to control and monitor the performance of software processes [29].

At present software measurement is in a status in which terminologies, methods and principles are still being defined and combined. We should not expect to find quantitative laws that are mostly valid and usable, and have the same accuracy and precisions as the laws of physics. The definition of usable measures and internationally valid may be long term and ideal research goal, which cannot be realized in the nearer future [6]. Software engineering measurements is not similar to quantitative laws of physics. Specific measurements such as mass, voltage, temperature, or velocity are unusual in the software engineering field. Because software measurements are often indirect, they are open to controversy [33]. There is insufficiency of an agreed-upon framework of validation metrics [16]. The goal of software measures is to enhance the software development [9].

The Software Engineering Institute (SEI) started a study for determining the capability of software contractors in the mid-1980s. The conclusion of this capability evaluation was the Software Capability Maturity Model for Software (CMM/SW) [32]. There is other capability maturity models were improved, such as the People Capability Maturity Model (P- CMM) [7].

Software Engineering Institute (SEI) and some other associations shared the same field are get together to develop the CMMI software framework, a set of combined CMMI models.

In United State (USA) the Department of Defense and other government parts use the Capability Maturity Model Integrated (CMMI) for process improvement to reduce the risk of poor working of developer contractors. The CMMI is used widely and it is a comprehensive framework for improving the processes of organizations that produce complex products [34]. 
International Journal of Computer Science \& Engineering Survey (IJCSES) Vol.5, No.3, June 2014

CMMI framework provides technical guidelines to achieve a particular level of process development quality. The main objective of CMMI is to enhance the quality the produced software according to final user's requirements. Using models such as CMMI model to assess quality of software is not only a minimum need for organization's existence but also a business strategy [30].

CMMI model includes the following materials [1]:

1. Materials which help evaluating the meaning of your processes, this information is essential for both administrative activities and technical help activities.

2. Materials which help improving process performance, this information are used to increase the capability in the targeted organizations.

Through the process of choosing CMMI, we try to realize the following objectives: 1-Improving project management capability; 2- Enhancing product quality; 3- Increasing productivity and cost down; 4- Improving the capability of estimating the project budget and schedule; 5- Increasing customer satisfaction [27].

CMMI framework is a comprehensive model. CMMI covers many subjects of information in software production, defined many Process Areas (PA), generic goals and generic practices, specific goals and specific practices, and a lot of work products. CMMI framework is used to enhance processes, increase production and increase competitiveness of an organization [39].

CMMI framework is a well known and widely used process improvement. Goal realizing is used in appraisal as the basis for determining whether a process area has been satisfied. CMMI framework is a well structured quality approach which is clearly defines its activities in an easy to recognize text styles [20].

In each selected process area in $\mathrm{CMMI} / \mathrm{SW}$, there are generic goals and related generic practices, and specific goals and related specific practices. Each specific goal relates to a process area and concentrates on the related properties that describe what must be done to accept the process area. A specific practice is considered as an important activity in realizing the associated specific goal. However, specific practices are recognized by CMMI as goals rather than the ways that we reach the goal [37].

Software process improvement becomes the key to the existence of most software development organizations. CMMI can help in setting process improvement goals and provide guidance for quality processes. CMMI framework supports process and product improvement, reduces redundancy and eliminates inconsistency because of using multiple standalone models. The CMMI is designed to cover all processes in the software development life cycle and involve a wide range of systems and products [38].

Goal-Question-Metric (GQM) is an approach that identifies process metrics, it was developed by Basili and Weiss [4] as an approach for identifying meaningful metrics for software development processes. GQM has proven that it is an efficient approach to selecting and implementing metrics.

This paper defines measures for the two specific goals and its four specific practices of Process and Product Quality Assurance which is one of the process areas in level 2 in CMMI-SW (Staged Representation) model. Measures will be compatible with the four specific practices associated with the two specific goals of Process and Product Quality Assurance PA. The measures will be 
International Journal of Computer Science \& Engineering Survey (IJCSES) Vol.5, No.3, June 2014

determined by applying the Goal-Question-Metrics (GQM) approach to the two specific goals and its four specific practices of Process and Product Quality Assurance PA. The determined measures will be helpful when used for evaluation and control the software products and processes.

The remainder of the paper is arranged as the following: section two describes the relative work in software development measurement for the $\mathrm{CMMI} / \mathrm{SW}$, section three presents an overview of the CMMI/SW, section four presents an overview of the (GQM), section five describes the application of the (GQM) to the CMMI/SW and defines the measures, section six describes the validity and reliability of the defined measures for Process and Product Quality Assurance process area, and section seven presents conclusions.

\section{RELATED WORK}

Many software measures researches have been suggested in the literature, some of them are [5] [14] [17] [21] [22] [23] [24] [28] [32]. The most related to our work are [5] [28] [32] [21] [22] [23] and [24]. The study of Baumert and McWhinney [5] defines a set of indicators that are convenient with the measurement practice (a common features) described in the Capability Maturity Model for CMM/SW. The defined indicators cover thirteen categories; categories don't occur at all of the maturity levels. Baumert and McWhinney don't concentrate on a specific process. There work was related to CMM not CMMI.

Paulk, Weber, Garcia, Crissis and Bush [32] identify a set of examples of metrics in measurement practice (one of the common features) of the Capability Maturity Model for Software (CMM/SW) in Key Process Areas (KPAs). In there research they defined a few examples related to requirements management KPA. They don't concentrate on a specific process. Their work was based on $(\mathrm{CMM} / \mathrm{SW})$ not on $(\mathrm{CMMI} / \mathrm{SW})$. Loconsole [28] defined measures for the Requirements Management Key Process Area of the CMM/SW. Her work was based on (CMM/SW) not on (CMMI/SW). Khraiwesh [21] [22] [23] [24] provided measurements for Requirements Validation, Risk Management, Project Planning, and Project Monitoring and Control process areas of the CMMI/SW.

This paper provides a set of general measures that are related to a specific PA, which is Process and Product Quality Assurance PA of the CMMI/SW. The defined measures are for the two specific goals and the related four specific practices of Process and Product Quality Assurance PA.

\section{OVERVIEW OF THE CMMI-SW}

The CMMI/SW (Staged Representation) consists of five levels of maturity: Initial, Managed, Defined, Quantitatively Managed and Optimizing, which are shown in Figure 1. Each maturity level contains several process areas excluding Level1 [35].

Each process area in (CMMI/SW) has generic goals with related generic practices and one or more specific goals with related specific practices. The generic goals are related to the institutionalization of suitable practices, they called generic because the same goal related to multiple process areas as shown in figure 2. The specific goal is related to the process area and handles the features that only describe what must be implemented to complete the process area. The specific practice is an action that must be implemented to complete the associated specific goal [35]. 
The purpose of Process and Product Quality Assurance (PPQA) is to provide an understanding for the project progress and to take a suitable action when the project deviates from the plan. The documented plan is the base for tracking activities. Progress is usually determined by comparing the plan to effort, cost, schedule, and work product [35].

In the following we will list the specific goals related to Process and Product Quality Assurance process area and the specific practices related to each specific goal:

\section{1- Objectively Evaluate Processes and Work Products}

1.1 Objectively Evaluate Processes

1.2 Objectively Evaluate Work Products

2- Provide Objective Insight

2.1 Communicate and Resolve Noncompliance Issues

2.2 Establish Records

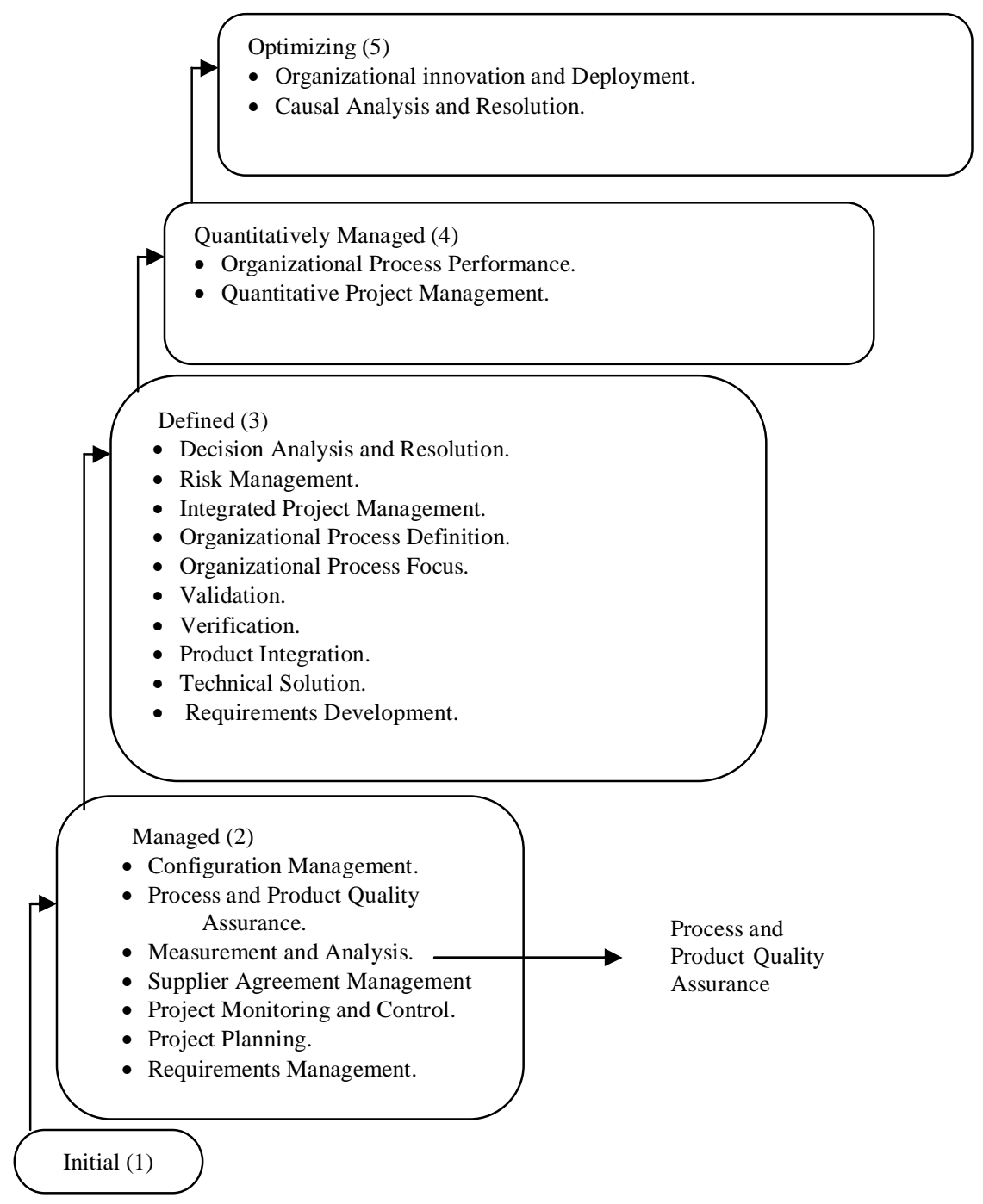

Figure 1. The five levels in CMMI with Process Areas 


\section{OVERVIEW OF THE GQM}

The Goal/Question/Metric (GQM) paradigm is a process which helps organizations to concentrate the measurement activity on their goals. GQM declares that an organization should have defined goals before they collected data [2]. The more mature your process is, the more that it is visible and therefore measurable. GQM does not define fix goals, it is in fact an approach which defines goals and revises them into a set of quantifiable questions, and these questions present a specific set of measures and collected data lead to realize these goals.

The GQM paradigm consists of three steps:

1. Define a set of goals related to the needs of the organization and its projects. Determine what should be learned or improved. The goals can be determines as purpose, perspective, and environment. Measurement goals should be defined in a clear structure and an understandable way. We do this by identifying the purpose (what object and why), viewpoint (what aspect and who), and characteristics of context [3].

2. Generate a set of quantifiable questions. The defined goals are moved to quantifiable questions with a concentration on measuremen. Basili and Rombach [2] define different sets of recommendations to classify questions associated to processes or products.

3. Define series of measures that suit the quantitative information we need to answer the defined quantifiable questions. In this phase, we define the measures proper to provide information to answer the questions and join them to each question. Various metrics may be generated from one goal. Various measurements may be needed to answer a single question. One measurement may apply to more than one question.

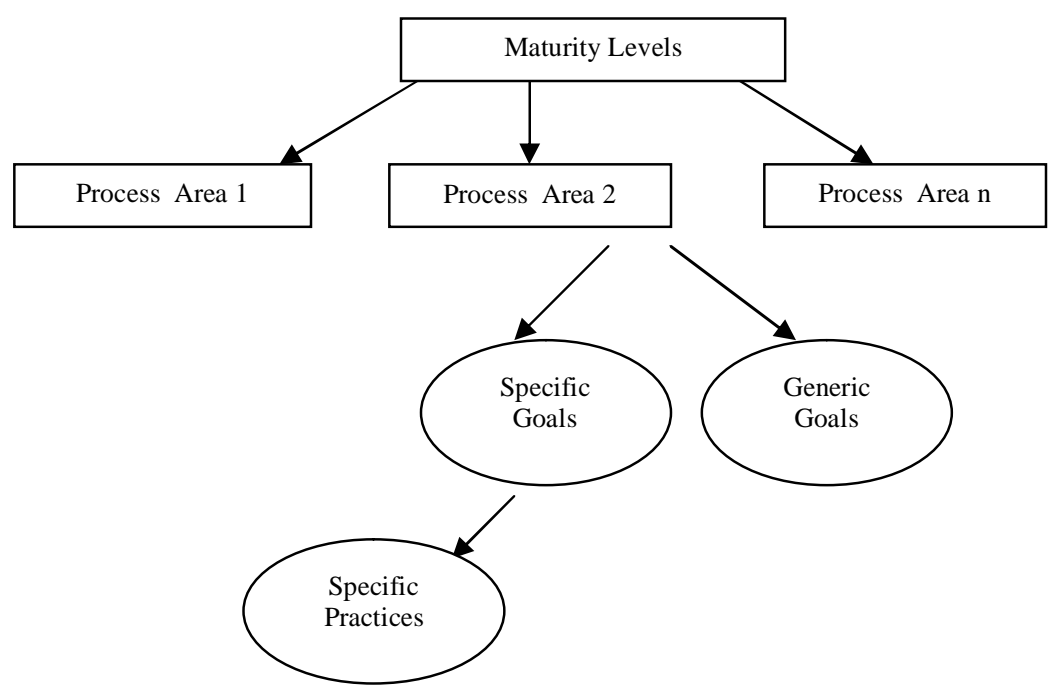

Figure 2. specific and generic goals 


\section{APPLYING GQM to The CMMI-SW}

The CMMI/SW defines two specific goals for Process and Product Quality Assurance PA. There are four specific practices related to the specific goals. We consider the specific practices as goals. We will apply the GQM on the four specific practices.

The four specific practices associated with Process and Product Quality Assurance process area are:

1- Objectively Evaluate Processes: Evaluate objectively selected performed processes against applicable process descriptions, procedures, and standards.

2- Objectively Evaluate Work Products: Evaluate objectively selected work products against applicable process descriptions, procedures, and standards.

3- Communicate and Resolve Noncompliance Issues: Connect quality issues and confirm the resolution of noncompliance issues with managers and staff.

4- Establish Records: Build and maintain registers of quality assurance activities.

These four specific practices can be used as goals for the first step of the GQM. The second phase in the GQM approach is to generate a set of quantifiable questions related to the four specific practices. The third phase of the GQM is to determine a set of measures that provide the needed quantitative information to answer the generated questions. Normal work products and sub practices which are mentioned in each of the four specific practices are take into account when we define the measures.

A collection of questions and measures are given in the following tables, table 1 to table 4 , each table represents one specific practice. There are interfering between the questions and between the measures. The same measure can be used to provide information to answer different generated questions.

\subsection{Measures for specific practice 1}

Objectively Evaluate Processes: Evaluate objectively selected performed processes against applicable process descriptions, procedures, and standards.

1. A collection of questions and measures are given in the following table related to specific practice

Table 1. collection of questions and measures related to specific practice 1.

\begin{tabular}{|l|l|l|}
\hline & Questions & Measures \\
\hline Q1 & $\begin{array}{l}\text { Do you evaluate objectively selected } \\
\text { performed processes against } \\
\text { applicable process descriptions, } \\
\text { procedures, and standards? }\end{array}$ & $\begin{array}{l}\text { - Evaluating selected performed } \\
\text { processes. }\end{array}$ \\
& -\# Selected performed processes. \\
& $\begin{array}{l}\text { - \# Standards. } \\
\text { - \# Procedures. } \\
\text { (\# means number of })\end{array}$ \\
\hline
\end{tabular}




\begin{tabular}{|c|c|c|}
\hline Q2 & $\begin{array}{l}\text { Do you provide a description of the } \\
\text { quality assurance reporting chain and } \\
\text { how it ensures objectivity? }\end{array}$ & $\begin{array}{l}\text { - providing a description of the quality } \\
\text { assurance reporting chain. }\end{array}$ \\
\hline Q3 & $\begin{array}{l}\text { Do you produce evaluation reports, } \\
\text { noncompliance reports? }\end{array}$ & $\begin{array}{l}\text { - Producing evaluation reports, } \\
\text { noncompliance reports. } \\
\text { - \# Evaluation reports. } \\
\text { - \# Noncompliance reports. }\end{array}$ \\
\hline Q4 & Do you specify a corrective action? & $\begin{array}{l}\text { - Specifying a corrective action. } \\
\text { - \# Corrective actions. }\end{array}$ \\
\hline Q5 & $\begin{array}{l}\text { Do you promote an environment that } \\
\text { encourages the staff in identifying } \\
\text { and reporting quality issues? }\end{array}$ & $\begin{array}{l}\text { - Promoting an environment that } \\
\text { encourages the staff. } \\
\text { - \# Staff in the quality assurance } \\
\text { environment. }\end{array}$ \\
\hline Q6 & $\begin{array}{l}\text { Do you define and maintain clearly } \\
\text { stated criteria for valuation based on } \\
\text { business needs? }\end{array}$ & $\begin{array}{l}\text { - Defining and maintaining clearly } \\
\text { stated criteria for valuation. } \\
\text { - \# Criteria for valuation. }\end{array}$ \\
\hline Q7 & $\begin{array}{l}\text { Do you identify what will be } \\
\text { evaluated? }\end{array}$ & $\begin{array}{l}\text { - Identifying what will be evaluated. } \\
\text { - } \quad \text { \# Selected performed processes. }\end{array}$ \\
\hline Q8 & $\begin{array}{l}\text { Do you identify how the evaluation } \\
\text { will be performed? }\end{array}$ & $\begin{array}{l}\text { - Identifying how the evaluation will } \\
\text { be performed. }\end{array}$ \\
\hline Q9 & $\begin{array}{l}\text { Do you identify how often a process } \\
\text { will be evaluated? }\end{array}$ & $\begin{array}{l}\text { - Identifying how often a process will } \\
\text { be evaluated. } \\
\text { - \# Evaluations in a period of time. }\end{array}$ \\
\hline $\begin{array}{l}\text { Q1 } \\
0\end{array}$ & $\begin{array}{l}\text { Do you identify who must be } \\
\text { involved in the evaluation? }\end{array}$ & $\begin{array}{l}\text { - Identifying who must be involved in } \\
\text { the evaluation. } \\
\text { - \# Persons involved in the evaluation. }\end{array}$ \\
\hline $\begin{array}{l}\text { Q1 } \\
1\end{array}$ & $\begin{array}{l}\text { Do you identify every noncompliance } \\
\text { found during the evaluation? }\end{array}$ & $\begin{array}{l}\text { - Identifying every noncompliance } \\
\text { found during the evaluation. } \\
\text { - \# Noncompliance found. }\end{array}$ \\
\hline $\begin{array}{l}\text { Q1 } \\
2\end{array}$ & $\begin{array}{l}\text { Do you identify lessons learned in } \\
\text { order to improve processes? }\end{array}$ & $\begin{array}{l}\text { - Identifying lessons learned in order to } \\
\text { improve processes. } \\
\text { - \# Lessons learned. }\end{array}$ \\
\hline
\end{tabular}

\subsection{Measures for specific practice 2 .}

Objectively Evaluate Work Products: Evaluate objectively selected work products against applicable process descriptions, procedures, and standards.

2.A collection of questions and measures is given in the following table related to specific practice 
International Journal of Computer Science \& Engineering Survey (IJCSES) Vol.5, No.3, June 2014

Table 2. Collection of questions and measures related to specific practice 2

\begin{tabular}{|c|c|c|}
\hline & Questions & Measures \\
\hline Q1 & $\begin{array}{l}\text { Do you evaluate objectively selected } \\
\text { work products against process } \\
\text { descriptions, procedures, and standards? }\end{array}$ & $\begin{array}{l}\text { - Evaluating selected work products } \\
\text { against process descriptions procedures, } \\
\text { and standards. } \\
\text { - \# Work products. }\end{array}$ \\
\hline Q2 & $\begin{array}{l}\text { Do you produce evaluation reports and } \\
\text { noncompliance reports? }\end{array}$ & $\begin{array}{l}\text { - Producing evaluation reports and } \\
\text { noncompliance reports. } \\
\text { - \# Evaluation reports. } \\
\text { - \# Noncompliance reports. }\end{array}$ \\
\hline Q3 & Do you specify a corrective action? & $\begin{array}{l}\text { - Specifying a corrective action. } \\
\text { - \# corrective actions. }\end{array}$ \\
\hline Q4 & $\begin{array}{l}\text { Do you select work products to be } \\
\text { evaluated based on documented criteria? }\end{array}$ & $\begin{array}{l}\text { - Selecting work products to be evaluated. } \\
\text { - \# work products to be evaluated. }\end{array}$ \\
\hline Q5 & $\begin{array}{l}\text { Do you establish and maintain clearly } \\
\text { stated criteria for the evaluation of work } \\
\text { products based on business needs? }\end{array}$ & $\begin{array}{l}\text { - Establishing and marinating clearly } \\
\text { stated criteria for the evaluation of work } \\
\text { products. } \\
\text { - \# Criteria for the evaluation. }\end{array}$ \\
\hline Q6 & Do you identify what will be evaluated? & $\begin{array}{l}\text { - Identifying what will be evaluated. } \\
\text { - \# Work products to be evaluated. }\end{array}$ \\
\hline Q7 & $\begin{array}{l}\text { Do you identify how often a work } \\
\text { product will be evaluated? }\end{array}$ & $\begin{array}{l}\text { - Identifying how often a work product } \\
\text { will be evaluated. } \\
\text { - \# Evaluations in a period of time. }\end{array}$ \\
\hline Q8 & $\begin{array}{l}\text { Do you identify how the evaluation will } \\
\text { be performed? }\end{array}$ & $\begin{array}{l}\text { - Identifying how the evaluation will be } \\
\text { performed. }\end{array}$ \\
\hline Q9 & $\begin{array}{l}\text { Do you identify who must be involved in } \\
\text { the evaluation? }\end{array}$ & $\begin{array}{l}\text { - Identifying who must be involved in the } \\
\text { evaluation. } \\
\text { - \# Persons involved in the evaluation. }\end{array}$ \\
\hline Q10 & $\begin{array}{l}\text { Do you evaluate selected work products } \\
\text { during unit testing and integration? }\end{array}$ & $\begin{array}{l}\text { - Evaluating selected work products } \\
\text { during unit testing and integration. } \\
\text { - \# selected work products during unit } \\
\text { testing. } \\
\text { - \# selected work products during } \\
\text { integration. }\end{array}$ \\
\hline Q11 & $\begin{array}{l}\text { Do you evaluate selected work products } \\
\text { before delivery to the customer, during } \\
\text { delivery to the customer and } \\
\text { incrementally when it is appropriate? }\end{array}$ & $\begin{array}{l}\text { - Evaluating selected work products } \\
\text { before delivery to the customer, during } \\
\text { delivery to the customer and } \\
\text { incrementally when it is appropriate. } \\
\text { - \# selected work products before } \\
\text { delivery. } \\
\text { - \# selected work products during } \\
\text { delivery. } \\
\text { - \# selected work products incrementally }\end{array}$ \\
\hline
\end{tabular}


International Journal of Computer Science \& Engineering Survey (IJCSES) Vol.5, No.3, June 2014

\begin{tabular}{|l|l|l|}
\hline & & when it is appropriate. \\
\hline Q12 & $\begin{array}{l}\text { Do you identify every case of } \\
\text { noncompliance found? }\end{array}$ & $\begin{array}{l}\text { - Identifying every case of } \\
\text { noncompliance found. } \\
\text { \# Noncompliance found. }\end{array}$ \\
\hline Q13 & $\begin{array}{l}\text { Do you identify lessons learned to } \\
\text { improve processes? }\end{array}$ & $\begin{array}{l}\text { - Identify lessons learned to improve } \\
\text { processes. } \\
\text { \# Lessons learned. }\end{array}$ \\
\hline
\end{tabular}

\subsection{Measures for specific practice 3 .}

Communicate and Resolve Noncompliance Issues: connect quality issues and confirm the resolution of noncompliance issues with managers and staff..

A collection of questions and measures is given in the following table related specific practice 3 .

Table 3. Collection of questions and measures related to specific practice 3

\begin{tabular}{|c|c|c|}
\hline & Questions & Measures \\
\hline Q1 & $\begin{array}{l}\text { Do you connect quality issues and ensure } \\
\text { the solution of noncompliance issues } \\
\text { with the managers, and staff ? } \\
\text { (Noncompliance issues are the identified } \\
\text { problems in evaluations that show the } \\
\text { lack of commitment to standards, process } \\
\text { descriptions, or procedures). }\end{array}$ & $\begin{array}{l}\text { - Connecting quality issues and ensures } \\
\text { the solution of noncompliance issues. } \\
\text { - \# Noncompliance issues. }\end{array}$ \\
\hline Q2 & $\begin{array}{l}\text { Do you identify the status of } \\
\text { noncompliance issues which provides an } \\
\text { indication of quality trends? }\end{array}$ & $\begin{array}{l}\text { - Identifying the status of noncompliance } \\
\text { issues. } \\
\text { - \# Noncompliance. }\end{array}$ \\
\hline Q3 & $\begin{array}{l}\text { Do you track the noncompliance issues } \\
\text { to reach a resolution? }\end{array}$ & $\begin{array}{l}\text { - Tracking the noncompliance issues to } \\
\text { reach a resolution. } \\
\text { - \# Resolved noncompliance. }\end{array}$ \\
\hline $\mathrm{Q} 4$ & $\begin{array}{l}\text { Do you identify corrective action reports } \\
\text { and evaluation reports? }\end{array}$ & $\begin{array}{l}\text { - Identifying corrective action reports and } \\
\text { evaluation reports. } \\
\text { - \# Corrective action reports. } \\
\text { - \# Evaluation reports. }\end{array}$ \\
\hline Q5 & Do you identify the quality trends? & $\begin{array}{l}\text { - Identifying the quality trends. } \\
\text { - Level of quality trend. }\end{array}$ \\
\hline Q6 & $\begin{array}{l}\text { Do you resolve every noncompliance } \\
\text { with the appropriate member staff? }\end{array}$ & $\begin{array}{l}\text { - Resolving every noncompliance with } \\
\text { the appropriate member staff. } \\
\text { - \# Member staff share the resolving. }\end{array}$ \\
\hline
\end{tabular}


International Journal of Computer Science \& Engineering Survey (IJCSES) Vol.5, No.3, June 2014

\begin{tabular}{|c|c|c|}
\hline Q7 & $\begin{array}{l}\text { Do you document non compliance issues } \\
\text { which can't be resolved? }\end{array}$ & $\begin{array}{l}\text { - Documenting noncompliance issues } \\
\text { which can't be resolved. } \\
\text { - \# Noncompliance issues which can't be } \\
\text { resolved. }\end{array}$ \\
\hline Q8 & $\begin{array}{l}\text { Do you escalate unresolved compliance } \\
\text { issues to the appropriate level of } \\
\text { management? }\end{array}$ & $\begin{array}{l}\text { - Escalating unresolved noncompliance } \\
\text { issues to the appropriate level. } \\
\text { - \# Unresolved noncompliance. }\end{array}$ \\
\hline Q9 & $\begin{array}{l}\text { Do you analyze noncompliance issues to } \\
\text { find the quality trends that can be } \\
\text { identified and addressed? }\end{array}$ & $\begin{array}{l}\text { - Analyzing noncompliance issues to find } \\
\text { the quality trends. } \\
\text { - Level of quality trend. }\end{array}$ \\
\hline Q10 & $\begin{array}{l}\text { Do you ensure that relevant stakeholders } \\
\text { are familiar with the results of evaluation } \\
\text { and quality trends? }\end{array}$ & $\begin{array}{l}\text { - Ensuring that relevant stakeholders are } \\
\text { familiar with the results of evaluation } \\
\text { and quality trends. } \\
\text { - \# Stakeholders involved. }\end{array}$ \\
\hline Q11 & $\begin{array}{l}\text { Do you review periodically open } \\
\text { noncompliance issues and trends with } \\
\text { the assigned manager? }\end{array}$ & $\begin{array}{l}\text { - Reviewing open noncompliance issues } \\
\text { and trends with the assigned manager. } \\
\text { - \# Reviewing open noncompliance } \\
\text { issues. }\end{array}$ \\
\hline Q12 & $\begin{array}{l}\text { Do you track noncompliance issues to } \\
\text { resolution? }\end{array}$ & $\begin{array}{l}\text { - Tracking noncompliance issues to } \\
\text { resolution. } \\
\text { - \# Tracking noncompliance issues. } \\
\text { - \# Resolved noncompliance. }\end{array}$ \\
\hline
\end{tabular}

\subsection{Measures for specific practice 4 .}

Establish Records: Build and maintain registers of quality assurance activities.

4. A collection of questions and measures is given in the following table related to specific practice

Table 4. Collection of questions and measures related to practice 4

\begin{tabular}{|l|l|l|}
\hline & Questions & Measures \\
\hline Q1 & $\begin{array}{l}\text { Do you build and maintain records of } \\
\text { quality assurance activities? }\end{array}$ & $\begin{array}{l}\text { - Building and maintaining records of } \\
\text { quality assurance activities. }\end{array}$ \\
\hline Q2 & Do you establish evaluation logs? & $\begin{array}{l}\text { - Establishing evaluation logs. } \\
\text { - \# Evaluations in a period of time. }\end{array}$ \\
\hline Q3 & $\begin{array}{l}\text { Do you establish quality assurance } \\
\text { reports? }\end{array}$ & $\begin{array}{l}\text { - Establishing quality assurance reports. } \\
\text { - \# Quality assurance reports. }\end{array}$ \\
\hline Q4 & $\begin{array}{l}\text { Do you establish status reports of } \\
\text { corrective actions? }\end{array}$ & $\begin{array}{l}\text { - Establishing status reports of corrective } \\
\text { actions. } \\
\text { - \# Corrective actions reports. }\end{array}$ \\
\hline Q5 & $\begin{array}{l}\text { Do you establish reports of quality } \\
\text { trends? }\end{array}$ & $\begin{array}{l}\text { - Establishing reports of quality trends. } \\
\text { - \# quality trends reports. }\end{array}$ \\
\hline
\end{tabular}




\begin{tabular}{|l|l|l|}
\hline Q6 & $\begin{array}{l}\text { Do you record process and product } \\
\text { quality assurance activities in suitable } \\
\text { detail? }\end{array}$ & $\begin{array}{l}\text { - Recording process and product quality } \\
\text { assurance activities in suitable detail. }\end{array}$ \\
\hline Q7 & $\begin{array}{l}\text { Do you review the status and history of } \\
\text { quality assurance activities as necessary? }\end{array}$ & $\begin{array}{r}\text { - Reviewing the status and history of } \\
\text { quality assurance activities. } \\
\text { - \# Reviewing the status of quality } \\
\text { assurance activities. } \\
\text { - \# Reviewing the history of quality } \\
\text { assurance activities. }\end{array}$ \\
\hline
\end{tabular}

\section{VALIDITY AND RELIABILITY OF THE DEFINED MEASURES}

We have made a questionnaire to examine the validity and reliability of the defined measures for Process and Product Quality Assurance PA and confirm that they are actually measure the ten specific practices. We will test the data we collected using cronbach alpha reliability in SPSS.

The questionnaire was reviewed and confirmed by practitioners in software building and academics in software engineering in Zarqa University. The questionnaire was filled by software developers, designers, and students in information technology departments. The questionnaire consists of four sections, each section is related to one of the four specific practices of the Process and Product Quality Assurance process, each section consists of a group of statements (measures) related to the specific practice, beside each statement there is five options: strongly agree, agree, neither agree nor disagree, disagree, strongly disagree. When questioner reads the statement he will write his opinion of the statement related to the specific practice by selecting one of the above five options, a sample shown in Appendix A.

Cronbach alpha is used to measure the internal consistency, which means, do all items measure the same thing? (Measure a single unidirectional structure). Cronbach alpha values are varying between 0 and 1 . There is a great internal consistency of items being assessed if alpha is closer to 1 [13]. If Cronbach alpha is less than 0.5 then internal consistencies is rejected [13]. When we apply the collected data on Cronbach Alpha we found alpha results between over 0.5 and less than 1.

\section{CONCLUSION}

Our paper defined general measures for Process and Product Quality Assurance Process Area (PA) in Capability Maturity Model Integration (CMMI-SW) for software development. We defined the measures by applying the Goal Question Metrics (GQM) paradigm to the two specific goals and its four specific practices of Process and Product Quality Assurance PA. Our paper concentrated on defining measures for a particular process area rather than defining measures for group of process areas.

The set of defined measures in the paper provide the organization with better insight into the activities related to Process and Product Quality Assurance, enhancing the development of software to the goal of having a matured process. The set of measures can be used to evaluate and control software products and processes. The Use of the defined measures determines by the software development process maturity in the organization. 
International Journal of Computer Science \& Engineering Survey (IJCSES) Vol.5, No.3, June 2014

\section{REFERENCES}

[1] Ahern, D. M., Clouse, A. and Turner, R., CMMI Distilled: A Practical introduction to Integrated Process Improvement. Second edition, Addison - Wesley, 2003.

[2] Basili, V. R. and Rombach, H. D., "The TAME Project: Towards Improvement-Oriented Software Environments", in IEEE Transactions on Software Engineering, vol. 14, no. 6, pp.758-773, 1988.

[3] Basili, V. R., Caldiera, C., Rombach, H. D., Goal Question Metric Paradigm, Encyclopedia of Software Engineering (Marciniak, J.J., editor), volume 1, John Wiley \& Sons, pp. 528-532, 1994.

[4] Basili, V. R., and Weiss, D. M., "A Methodology for collecting Valid Software Engineering Data", in IEEE Transactions on Software Engineering, volume. SE-10, pp.728-738, 1984.

[5] Baumert, J. H. and McWhinney, M. S., Software Measures and the Capability Maturity Model, Software Engineering Institute Technical Report, CMU/SEI-92-TR-25, ESC-TR-92-0, 1992.

[6] Briand, L.C., Morasca, S., and Basili, V. R., "An Operational Process for Goal Driven Definition of Measures", in IEEE Transactions on Software Engineering, vol. 28, no. 12, 2002.

[7] Curtis, B., Hefley, W. E., Miller, S. The People Capability Model : Guidelines for Improving the Workforce. Boston : Addison Wesley, 2001.

[8] Ebert, C. , Software Measurement for Better Project and Process Quality, UPGRADE (the European Journal for the Informatics Professional), Vol. x, No. 5, October, 2009.

[9] Ejiogu, L. O., " Five Principles for the Formal Validation of Models of Software Metrics ", ACM SIGPLAN Notices, Vol. 28,No. 8, August 1993.

[10] Fenton, N.E., and Pfleeger, S.L., Software Metrics - A Rigorous \& Practical Approach, 2nd Edition, International Thomson Publishing, Boston, MA, 1996.

[11] Fenton, N. E. \& Whitty, R. and Yoshinori, I. Software Quality Assurance and Measurement, A Worldwide Perspective. London: International Thomson Computer Press, 1995.

[12] Filipe, J., Shishkoy, B., Helfert, M. (Eds.): A Systematic Review Measurement in Software Engineering: State-of-the-Art in Measurement, RICSOFT 2006, CCIS vol. 10, pp. 165-176, 2008.( Springer-Verlag Berlin Heidelberg 2008.

[13] George, D. and Mallery, P., SPSS for windows step by step A Simple Guide and Reference, Fourth Edition, 2003.

[14] Hammer T. F., Huffman L. L., and Rosenberg L. H, "Doing requirements right the first time", in CROSSTALK, The Journal of Defence Software Engineering, December, pp. 20-25, 1998.

[15] Hwang, S., Essential Contents for Software Development Process and Software Quality Education, International Journal of Engineering Systems modeling and Simulation, Vol. 6, Nos. 1- 2, 2014.

[16] Jacquet, J. P. and Abran, A., "Metric Validation Proposals, A structured Analysis", 8th International Workshop on Software Measurement, Germany, Sept. 17-18, 1998.

[17] Janakiram. D and Rajasree. M. S, "ReQuEst: Requirements-driven Quality Estimator", in ACM SIGSOFT Software engineering notes, vol. 30, no.1, 2005.

[18] Jiang X., Xu L., Zhang X, and Bian Y, Study on Product Lifecycle Oriented Product Design Quality Control System, International Asia Conference on Industrial Engineering and Management Innovation (IEMI2012) Proceedings, pp 793-803, Springer-2013.

[19] Jones, C. , Implementing a Successful Measurement Program: Tried and True Practices and Tools, Cutter IT Journal, Vol. 11, No. 5, November, 2003.

[20] Z. D. Kelemen, R. Kusters, J. Trienekens, and K. Balla, "Towards Complexity Analysis of Software Process Improvement Frameworks,” Budapest, Technical Report TR201301, Sep. 2013.

[21] Khraiwesh, M., Requirements Validation Measures in CMMI, Mahmoud Khraiwesh, World of Computer Science and Information Technology Journal (WCSIT), Vo.1, No. 2, 26-33, 2011.

[22] Khraiwesh, M., Risk Management Measures in CMMI, International Journal of Software Engineering \& Applications (IJSEA), Vo. 3, No. 1, 149-163, January 2012.

[23] Khraiwesh, M., Project Planning Measures in CMMI, International Journal of Software Engineering \& Applications (IJSEA), Vo. 4, No. 2, 103-121, March 2013.

[24] Khraiwesh, M., Project Monitoring and Control in CMMI, Project Monitoring and Control Measures in CMMI, International Journal of Computer Science \& Information Technology (IJCSIT) Vol. 5, No. 5, October 2013. 
International Journal of Computer Science \& Engineering Survey (IJCSES) Vol.5, No.3, June 2014

[25] Kitchenham, B., Pfleeger, S.L., and Fenton, N., Towards a Framework for Software Measurement Validation, in IEEE Transactions on Software Engineering, 21(12), December 1995.

[26] Kitchenham, B., Jeffery, D. and Connaughton, C., Misleading Metrics and Unsound Analyses, IEEE Software, April 2007, Vol. 24, No. 2, pp. 73-78.

[27] Lee, Y, and Chen, J. Experience in introducing CMM to a telecommunication research organization, Journal of Software Engineering Studies, vol.1, No. 1, 8-16, September 2006.

[28] Loconsole, A., "Measuring the Requirements Management Key Process Area", Proceedings of ESCOM - European Software Control and Metrics Conference, London, UK, April, 2001.

[29] Mahinc, V. and Zabkar, N. Measurement repository for Scrum-based software development process. Conference on computer Engineering and Application (CEA,08) Acapulco, Mexico, January 25-27, 2008.

[30] Monterio, P., Machado, R., Kazman, R., Simoes, C., and Ribeiro, P.,RUP Alignment and Coverage Analysis of CMMI ML2 Process Areas for the Context of Software Project Execution, 6th International Conference, SWQD, 2014, Vienna, Austria, January 14-16, 2014, Proceedings.

[31] Park, R. E., Goethert, W. B. and Florac, W. A., Goal-Driven Software Measurement-A Guidebook, Software Engineering Institute Handbook, CMU/SEI-96- HB-002, August, 1996.

[32] Paulk, M. C., Weber, C. V., Garcia, S., Chrissis, M. B., and Bush, M., Key Practices of the Capability Maturity Model Version 1.1, Software Engineering Institute Technical Report, CMU/SEI-93- TR-25 ESC-TR-93-178, Pittsburgh, PA, USA, February, 1993.

[33] Pressman, R. S., Software engineering: A practitioner's Approach, Sixth edition, 2005.

[34] Pyster A., What Beyond CMMI Is needed to Help Assure Program and Project Success, SPW 2005, LNCS 3840, pp. 75 - 82, 2005. ( Springer-Verlag Berlin Heidelberg 2005.

[35] SEI (software Engineering Institute), CMMI (Capatility Maturity Model-Integrated) for development, V 1.3, Carnegie Mellon University, November 2010.

[36] Tomar A, and Thakare V.M., A customized Model on Software Quality Assurance \& Reuse, International Journal of Computer And Applications, Vol. 6, No. 2, Apr 2013, pp.279-284.

[37] Wu, C. S. , Simmons D. B., Software project planning Associate(SPPA): a knowledge based approach for dynamic software project planning and tracking, 24th International Computer Software and Application conference, (COMPSAC), Taiwan, October, 2000.

[38] Xiong W., and Cao Y., Comments on Software Process Improvement Methodologies Using QFD, Applied Mathematics \& Information Sciences Journal, Vol. 7, No. 3, 1137-1143, 2013.

[39] Young, H., Fang, T., and Hu, C. A successful practice of applying software tools to CMM1 process improvement, Journal of Software Engineering Studies, Vol. 1, No. 2, 78-95, December 2006.

\section{Questionnaire:}

\section{Appendix A Questionnaire and Analysis}

This questionnaire is related to the Process and Product Quality Assurance process. Process and Product Quality Assurance process provides an understanding of the proceeding in the project so that suitable corrective actions can be taken when the project deviates clearly from the plan.

The Process and Product Quality Assurance process has four goals:

1- Objectively Evaluate Processes

2- Objectively Evaluate Work Products

3- Communicate and Resolve Noncompliance Issues

4- Establish Records

We will measure the achievement of the above goals, thus, we define some sentences related to each goal. We suppose that the information in these sentences help us in achievement of the above four goals. 
Please, fill the enclosed form by writing down $\sqrt{ }$ in the proper place. Replying to the question: do you think that the sentences have an effect on the accomplishment of the goals?

1. Goal1: Objectively Evaluate Processes.

(Do you think that these sentences have an impact on the achievement of goal1: Objectively Evaluate Processes.)

\begin{tabular}{|c|c|c|c|c|c|c|}
\hline $\begin{array}{l}\text { stateme } \\
\text { nt } \\
\text { serial }\end{array}$ & statements & $\begin{array}{l}\text { Strongl } \\
\text { y } \\
\text { agree }\end{array}$ & Agree & $\begin{array}{l}\text { Neither } \\
\text { agree nor } \\
\text { disagree }\end{array}$ & $\begin{array}{l}\text { disagre } \\
\mathrm{e}\end{array}$ & $\begin{array}{l}\text { Strongly } \\
\text { disagree }\end{array}$ \\
\hline 1 & $\begin{array}{l}\text { Evaluating selected } \\
\text { performed } \\
\text { processes. }\end{array}$ & & & & & \\
\hline 2 & $\begin{array}{l}\text { Defining a } \\
\text { description of the } \\
\text { quality assurance } \\
\text { reporting chain. }\end{array}$ & & & & & \\
\hline 3 & $\begin{array}{l}\text { Producing } \\
\text { evaluation reports, } \\
\text { noncompliance } \\
\text { reports. }\end{array}$ & & & & & \\
\hline 4 & $\begin{array}{l}\text { Specifying a } \\
\text { corrective action. }\end{array}$ & & & & & \\
\hline 5 & $\begin{array}{l}\text { Promoting an } \\
\text { environment that } \\
\text { encourages the } \\
\text { staff. }\end{array}$ & & & & & \\
\hline
\end{tabular}

\section{Author}

Mahmoud khraiwesh is an associate professor at Faculty of Science and Information Technology in Zarqa University, Jordan. He got his master degree in computer science from Jordan University, Jordan, in 2002 and his doctorate degree in computer information system from The Arab Academy for Banking and Financial sciences, Jordan, in 2006. Dr. Khraiwesh area of research is in software development measures.

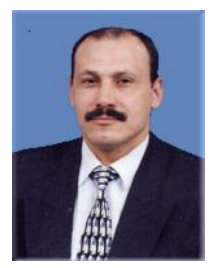

